\title{
Lymphoplasmacyte-Rich Meningioma of the Third Ventricle: Case Report
}

\section{Meningioma linfoplasmocítico do terceiro ventrículo: Relato de caso}

\author{
Marcelo Paglioli Ferreira1(1) Eduardo Cambruzzi ${ }^{10}$ Otávio Garcia Martins ${ }^{2(10}$ Guilherme Gago ${ }^{1(1)}$ \\ Antônio Delacy Martini Vial1ำ
}

${ }^{1}$ Department of Neurosurgery, Hospital São José, Complexo Hospitalar

Santa Casa de Misericórdia de Porto Alegre, Porto Alegre, rs, Brazil

2 Department of Neurosurgery, Universidade Federal de Pelotas, RS, Brazil

Address for correspondence Otávio Garcia Martins, MD, Universidade Federal de Pelotas, Pelotas, RS, 96010-610, Brazil

(e-mail: otvmartins@gmail.com).

Arq Bras Neurocir 2020;39(2):149-153.

\begin{abstract}
Keywords

- intracranial tumor

- meningioma

- lymphoplasmacyterich meningioma

- intraventricular tumor

- neuro-oncology
\end{abstract}

\section{Resumo}

received

October 8, 2019

accepted

January 27, 2020
Introduction Meningiomas are the most common primary intracranial tumors, accounting for up to $35 \%$ of the neoplasms in this category. Approximately $10-20 \%$ of these neoplasms are histologically atypical, and the lymphoplasmacyte-rich meningioma (LPM) corresponds to a very rare subtype of meningioma that is characterized histopathologically by massive infiltrates of inflammatory cells. The case described in the present study is the sixth case of an intraventricular LPM found in the literature and the first case considering the location in the third ventricle.

Case Description A 21-year-old male without previous comorbidities sought medical attention due to visual impairment (complaining of intermittent visual blur) for 2 months. A magnetic resonance imaging of the brain confirmed the presence of a well-delimited solid mass in the third ventricle of $3.0 \times 2.3 \mathrm{~cm}$ with a cystic component that extended itself inferiorly and distorted the visual pathway anatomy. Neurosurgeons decided to access the lesion using an interhemispheric transcallosal approach with a transforaminal access, and the lesion was resected completely. The patient has an ambulatorial endocrinological follow-up and is neurologically stable 6 months after the procedure. No new visual deficits were noted.

Conclusion Lymphoplasmacyte-rich meningioma is a very rare intracranial tumor, and the involvement of the third ventricle make this case unique

Introdução Os meningiomas são os tumores intracranianos primários mais comuns, responsáveis por até 35\% das neoplasias nessa categoria. Aproximadamente 10-20\% desses tumores são histologicamente atípicos, e o meningioma linfoplasmocítico (LPM) corresponde a um subtipo muito raro que é caracterizado histopatologicamente por infiltrados maciços de células inflamatórias. Este é o sexto caso encontrado na literatura de uma LPM intraventricular e o primeiro caso considerando a localização no terceiro ventrículo. 


\author{
Palavras-chave \\ - tumor intracraniano \\ - meningioma \\ - meningioma \\ linfoplasmocítico \\ - tumor \\ intraventricular \\ - neuro-oncologia
}

\begin{abstract}
Descrição do caso Um paciente do sexo masculino de 21 anos de idade, sem comorbidades anteriores, procurou atendimento médico devido a deficiência visual (queixa de borramento visual intermitente) por 2 meses. Foi submetido a uma ressonância magnética do cérebro que confirmou a presença de uma massa sólida bem delimitada no terceiro ventrículo de $3,0 \times 2,3 \mathrm{~cm}$, com um componente cístico que se estendia inferiormente e distorcia a anatomia da via óptica. Foi decidido acessar a lesão usando uma abordagem transcalosa inter-hemisférica com acesso transforaminal, e a lesão foi ressecada completamente. O paciente tem acompanhamento endocrinológico ambulatorial e está neurologicamente estável 6 meses após o procedimento. Nenhum novo déficit visual foi observado.

Conclusão A LPM é um tumor intracraniano muito raro, e o envolvimento do terceiro ventrículo torna esse caso único.
\end{abstract}

\section{Introduction}

Meningiomas are the most common primary intracranial tumors, accounting for up to $35 \%$ of the neoplasms in this category. ${ }^{1,2}$ Their origin is from arachnoid caput cells and, of the 16 subtypes recognized by World Health Organization (WHO) classification of tumors of the nervous system, the meningothelial, fibrous and transitional meningiomas are the most common. ${ }^{3}$ Approximately $10-20 \%$ of these neoplasms are histologically atypical, and the lymphoplasmacyte-rich meningioma (LPM) corresponds to a very rare subtype of meningioma that is characterized histopathologically by massive infiltrates of inflammatory cells, such as lymphocytes and plasma cells. ${ }^{3,4}$ Fewer than 110 cases of LPMs have been reported in the literature, most of which were isolated case reports. ${ }^{5,6}$

Regarding topography, most meningiomas develop in the cerebral convexity, parasagittal, or in the sphenoid ridge, and the LPMs follow this pattern of distribution. Intraventricular cases are considered very rare and occur in 0.5 to $3 \%$ of all meningiomas. ${ }^{7}$

The authors report the sixth case found in the literature of an intraventricular LPM (first case considering the third ventricle location) and describe the clinical and histopathological features of this rare pathology.

\section{Case Report}

A 21-year-old male, without previous comorbidities, sought medical attention due to visual impairment (complaining of intermittent visual blur) for 2 months. He was referred to an ophthalmologist, who found bilateral papilledema in the fundoscopy. The patient was sent to an emergency hospital, where he performed a computed tomography (CT) of the head that showed an expansion lesion in the third ventricle.

At neurological examination, there were no other deficits, such as weakness, paresthesias, loss of the visual field or other cranial nerves disturbances. The endocrinological evaluation did not indicate any disturbance of the hormonal axes. The investigation was complemented with a magnetic resonance imaging (MRI) of the brain, which confirmed the presence of a well-delimited solid mass in the $3^{\text {rd }}$ ventricle of $3.0 \times 2.3 \mathrm{~cm}$, with a cystic component that extended itself inferiorly and distorted the visual pathway anatomy ( - Fig. 1).

Due to the lesion characteristics, the hypothesis of craniopharyngioma was formulated. The patient was evaluated by the neurosurgery department, and surgical treatment was indicated due to the high risk of permanent visual deficit and deterioration by ventricular obstruction with the lesion growth.

Neurosurgeons decided to access the lesion using an interhemispheric transcallosal approach with a transforaminal access. It was noted during the intraoperative period that, in fact, the cystic component presented in the MRI was a septation of the third ventricle and was not part of the tumor itself. All the visualized tumor was resected using microsurgical technique, and tumoral material was collected and sent for histopathological analysis. At this point, the cyst was opened and its contents (motor oil aspect) were drained, decompressing the optic nerve.

The immunohistochemical and histological analysis confirmed the diagnosis of LPM, showing positive immunoexpression for epithelial membrane antigen (EMA) and cluster of differentiation 68 (CD68) (-Fig. 2).

After the surgery, the patient developed panhypopituitarism and diabetes insipidus, probably due to manipulation of the hypothalamus-pituitary pathways. In addition, he developed a right hemiparesis and paralysis of the left oculomotor nerve, probably due to surgical manipulation, that resolved almost completely in the postoperative period.

The postoperative MRI showed completed resection of the tumor (-Fig. 3). The patient has an ambulatorial endocrinological follow-up and is neurologically stable 6 months after the procedure. No new visual deficits were noted.

\section{Discussion}

The LPM was first described by Banerjee and Blackwood, in 1971, as a "subfrontal tumor with the features of plasmacytoma and meningioma" 8 and has been classified as grade I by the WHO since $1993 .^{5}$ According to a more recent series of 

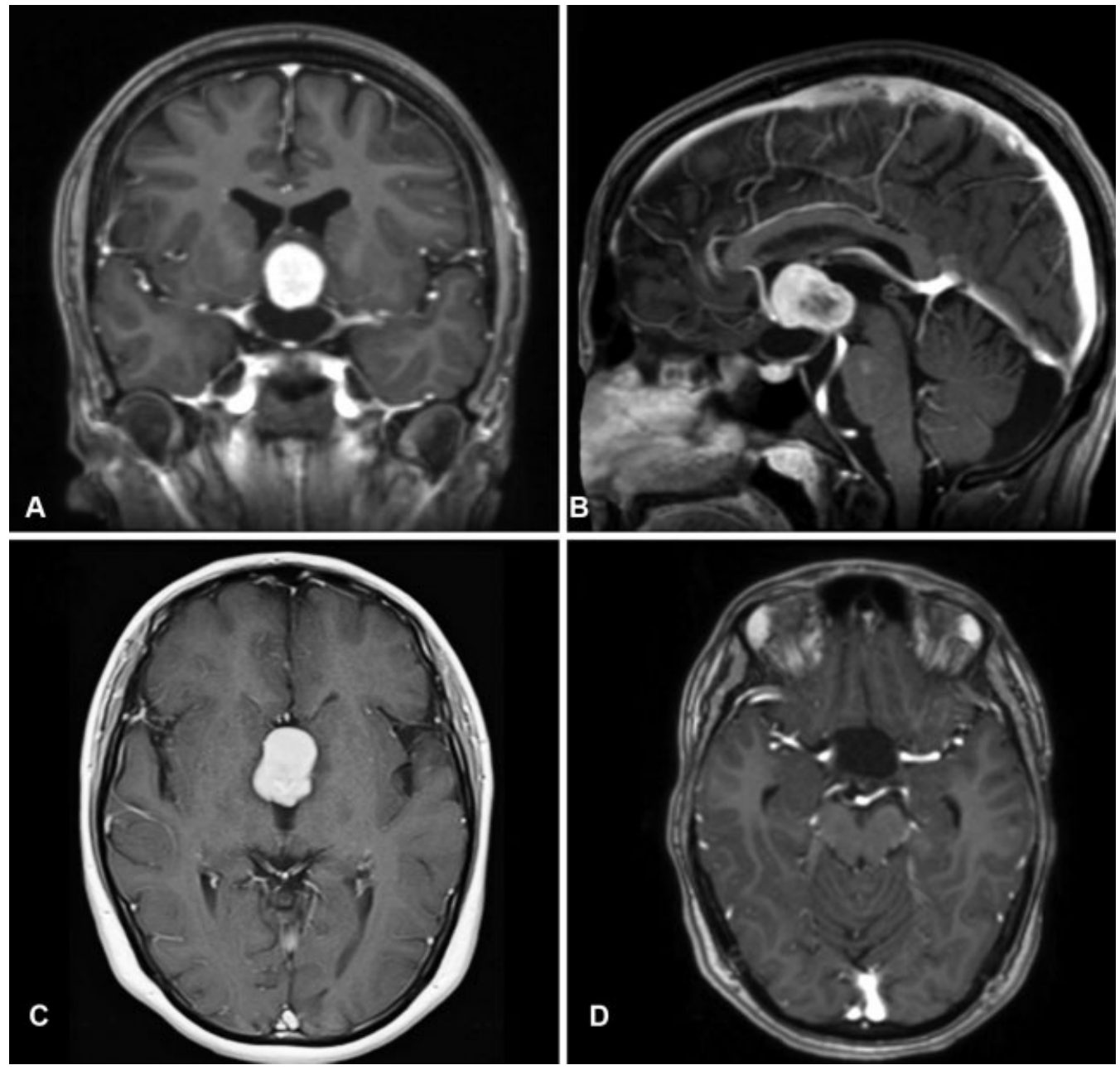

Fig. 1 Preoperative magnetic resonance imaging of the brain. T1 weighted with contrast injection images. (A) coronal view. (B) sagittal view. (C) axial view of the solid component. (D) axial view of the cystic component. An expansive lesion enhanced by contrast is noted on the floor of the third ventricle with a cystic component that exerted mass effect and distorted the visual pathway.

case, PML is diagnosed more frequently between the third and fifth decade of life (earlier than in meningiomas in general). Also, in contrast with regular meningiomas, there was no gender prevalence in LPMs. ${ }^{5}$

The epicenter of growth of the LPMs is similar to that found in meningiomas in general, with the cerebral convexity being the most common topography. The symptoms are associated with increased intracranial pressure (headache, nausea, vomiting, papilledema, and altered level of consciousness), and focal deficits are related to local brain compression caused by the tumor. ${ }^{5,6}$

Due to the classification in the WHO class I, LPMs are considered benign tumors with low rates of recurrence and aggressiveness. $^{3}$ Our case corresponded to this benign profile by presenting a low Ki67 index (less than $0.1 \%$ of the cells). Some reports in the literature point to a more malignant character of LPM, and these are associated with higher indices of the Ki67 ${ }^{9}$ and earlier neurological deterioration due to the infiltration of inflammatory cells in the cerebral parenchyma, but this characteristic was not noticed in the neuroimaging studies or in the transoperative scenario. $^{4,9}$
Regarding the histological characteristics, this tumor is marked by dense lymphocyte and plasma cell infiltration that occasionally overlies the meningeal epithelial cells. Immunohistochemically, expressions of certain markers, like EMA, vimentin, and CD68, are fundamental to confirm and distinguish the origin of the tumor. ${ }^{5,10}$ The differential diagnosis is important due to similar lesions that can mimic the LPM. Plasma cell granulomas (PCGs) are morphologically similar to LPMs and are difficult to differentiate. Plasma cell granulomas are characterized as non-neoplastic hyperplasia, which have massive infiltration of the lymphocytes, plasmacytes, and histiocytes. However, the typical meningioma morphology of a fibrous, spiral, or storiform shape is absent, and there is no positivity on the EMA and vimentin markers. ${ }^{10}$ Examples of other neoplasms that can mimic LPM include chordoid meningioma, multiple myeloma, solitary plasmacytoma, plasma cell granuloma, giant lymph node hyperplasia, and sinus histiocytosis. ${ }^{11}$

Lymphoplasmacyte-rich meningiomas of the ventricular system are extremely rare, and there are only 5 cases reported in the literature. ${ }^{5}$ Most cases occurred in the lateral ventricle, and there is no record of this type of meningioma 


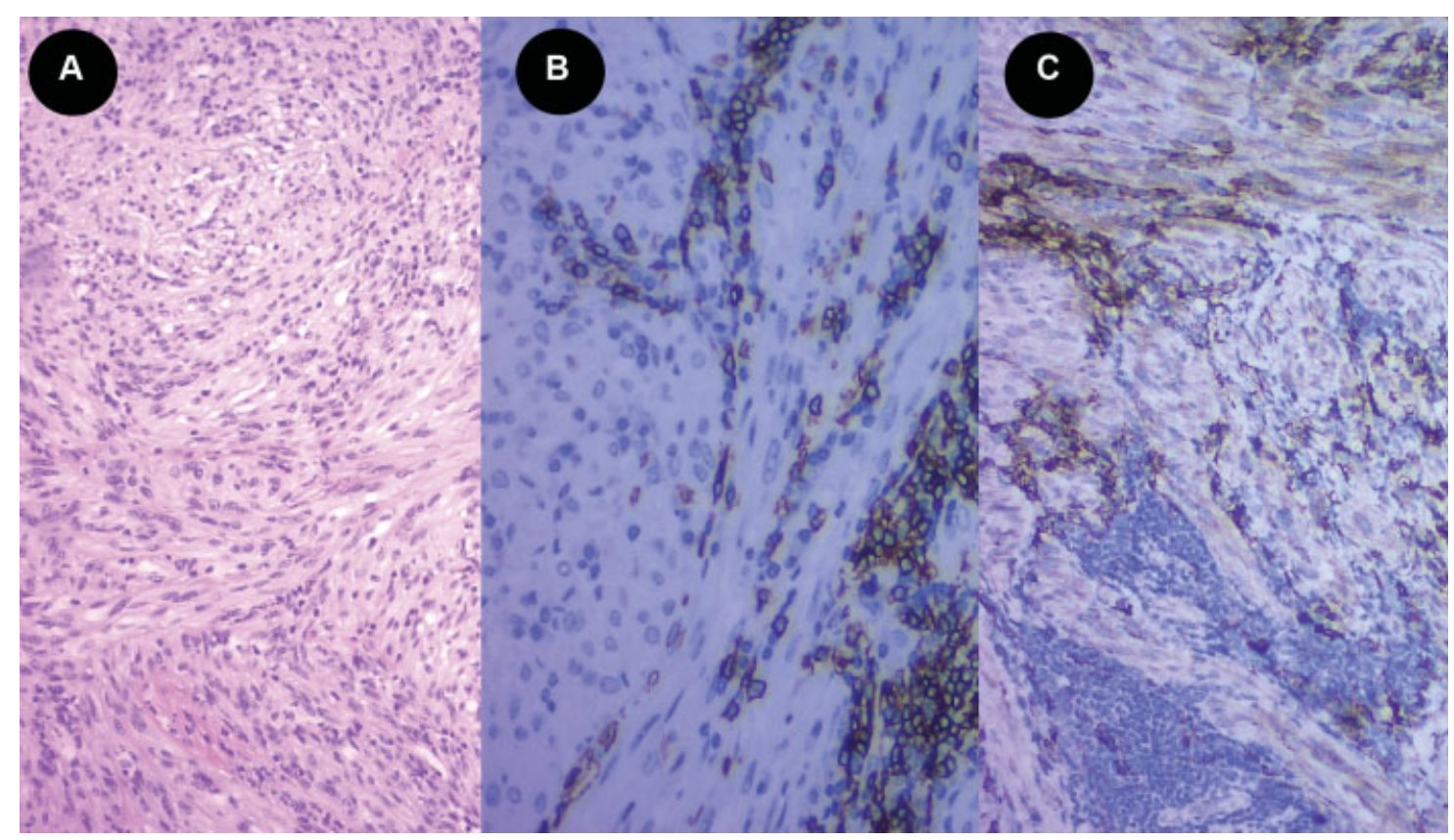

Fig. 2 Histopathological aspect of the lesion. (A) Lymphoplasmacyte-rich meningioma: Neoplastic meningothelial cells intermixed with numerous lymphocytes, macrophages, and plasma cells, hematoxylin and eosin, 100x. (B) meningothelial cells showing positive immunoexpression for epithelial membrane antigen, 200x. (C) Macrophages exhibiting positive immunoexpression for cluster of differentiation, 200x.
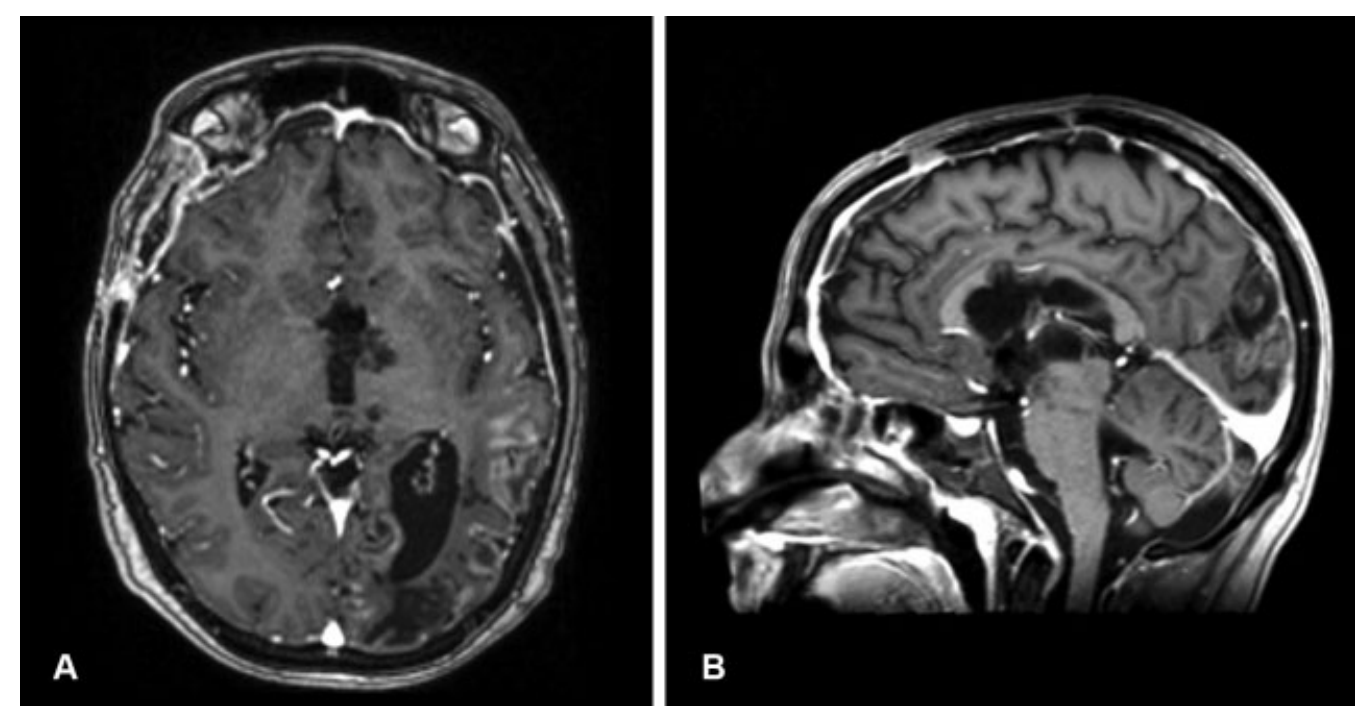

Fig. 3 Postoperative magnetic resonance imaging of the brain. T1 weighted with contrast injection images. (A) axial view. (B) sagittal view. Complete resection of the previous lesion.

affecting the third ventricle. Meningiomas of this location are a great therapeutic challenge due to the difficult surgical access as well as the risk of damaging important midline structures, such as the diencephalon.

Usually, these lesions are indicated for surgical treatment due to the rapid neurological deterioration and the risk of developing acute hydrocephalus by obstruction of the foramen of Monro. ${ }^{2}$ The approach method should be planned and individualized for the best optimization and effectiveness of the surgical procedure. Our case had a complex lesion involving the third ventricle and the suprachiasmatic cistern as well as an important relation with the optic pathway. Due to the location of the tumor, an interhemispheric transcallosal approach was chosen, which allowed a great visualization of the tumor and, consequently, complete macroscopic resection of the tumor. Despite the effort to preserve adjacent structures, the development of deficits due to surgical manipulation cannot be avoided.

\section{Conclusion}

Lymphoplasmacyte-rich meningioma is a very rare intracranial tumor, and the involvement of the third ventricle makes this case unique. The definitive diagnosis of LPM relies on 
histopathological findings and total surgical excision remains as the standard treatment for this type of tumor.

\section{Conflict of Interests}

The authors have no conflict of interests to declare.

\section{References}

1 Dolecek TA, Dressler EVM, Thakkar JP, Liu M, Al-Qaisi A, Villano JL. Epidemiology of meningiomas post-Public Law 107-206: The Benign Brain Tumor Cancer Registries Amendment Act. Cancer 2015;121(14):2400-2410

2 Whittle IR, Smith C, Navoo P, Collie D. Meningiomas. Lancet 2004; 363(9420):1535-1543

3 Louis DN, Perry A, Reifenberger G, et al. The 2016 World Health Organization Classification of Tumors of the Central Nervous System: a summary. Acta Neuropathol 2016;131(06):803-820http://www.ncbi.nlm.nih.gov/pubmed/27157931

4 Cambruzzi E, de Souza Tda C, Silveira LC, Moreira CF dos S. Lymphoplasmacyte-rich meningioma: a case report of a rare neoplasm. J Bras Patol Med Lab 2012;48(03):223-227
5 Tao X, Wang K, Dong J, et al. Clinical, Radiologic, and Pathologic Features of 56 Cases of Intracranial Lymphoplasmacyte-Rich Meningioma. World Neurosurgery 2017;106:152-164. DOI: 10.1016/j.wneu.2017.06.143

6 Zhu HD, Xie Q Gong Y, et al. Lymphoplasmacyte-rich meningioma: our experience with 19 cases and a systematic literature review. Int J Clin Exp Med 2013;6(07):504-515

7 Ødegaard KM, Helseth E, Meling TR. Intraventricular meningiomas: a consecutive series of 22 patients and literature review. Neurosurg Rev 2013;36(01):57-64, discussion 64

8 Banerjee AK, Blackwood W. A subfrontal tumour with the features of plasmocytoma and meningioma. Acta Neuropathol 1971; 18(01):84-88

9 Wang YB, Wang WJ, Xu SB, et al. Intraventricular lymphoplasmacyte-rich meningioma: a case report. Turk Neurosurg 2014;24 (06):958-962

10 Riemenschneider MJ, Perry A, Reifenberger G. Histological classification and molecular genetics of meningiomas. Lancet Neurol 2006;5(12):1045-1054

11 Loh JK, Hwang SL, Tsai KB, Kwan AL, Howng SL. Sphenoid ridge lymphoplasmacyte-rich meningioma. J Formos Med Assoc 2006; 105(07):594-598. Doi: 10.1016/S0929-6646(09)60156-X 